\title{
Comparison of Anolyte and Chlorine Dioxide for a Continuous Hot Water Disinfection in Nursing Home: A Two Years Legionnaires' Disease Prevention
}

\author{
Michele Totaro', Erica De Vita1, Serena Giorgi1, Sara Profeti' ${ }^{1}$, Andrea Porretta1, Antonio Gallo²,

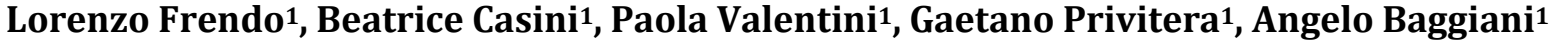 \\ ${ }^{1}$ Department of Translational Research and New Technologies in Medicine and Surgery, University of Pisa, Pisa, Italy \\ ${ }^{2}$ Division of Public Health and Nutrition, Area of Pisa, Azienda USL Toscana Nord Ovest, Pisa, Italy \\ Email: angelo.baggiani@med.unipi.it
}

How to cite this paper: Totaro, M., De Vita, E., Giorgi, S., Profeti, S., Porretta, A., Gallo, A., Frendo, L., Casini, B., Valentini, P., Privitera, G. and Baggiani, A. (2019) Comparison of Anolyte and Chlorine Dioxide for a Continuous Hot Water Disinfection in Nursing Home: A Two Years Legionnaires' Disease Prevention. Journal of Water Resource and Protection, 11, 233-243. https://doi.org/10.4236/jwarp.2019.113014

Received: January 18, 2019

Accepted: March 3, 2019

Published: March 6, 2019

Copyright $\odot 2019$ by author(s) and Scientific Research Publishing Inc. This work is licensed under the Creative Commons Attribution International License (CC BY 4.0).

http://creativecommons.org/licenses/by/4.0/

\begin{abstract}
Worldwide epidemiological reports assert that drinking water is a source for infections and Legionella control represents a critical issue in healthcare settings. Chemical disinfections of water networks are control measures that need to be fine-tuned to obtain satisfactory results in large buildings over prolonged time periods. Aim of study is the evaluation of the effect of anolyte and chlorine dioxide, applied in two different hot water networks of a nursing home to manage Legionella risk. Nursing home has two buildings (A and B), with the same point of aqueduct water entrance. From June 2016, following a shock chlorination, the continuous disinfections with chlorine dioxide and anolyte were applied in hot networks of building A and B, respectively. Hot water was sampled at the central heating system and at two points of use for Legionella research, while chemical tests of manganese $(\mathrm{Mn})$, iron (Fe), zinc $(\mathrm{Zn})$ and trihalomethanes compounds (THM) were implemented to evaluate the disinfection by-products presence. Before chlorination Legionella pneumophila sg1 was recovered with a mean count of $2.4 \times 10^{4} \mathrm{CFU} / \mathrm{L}$, while chemical compounds concentrations were within the law limits (Directive 98/83/EC). Then the disinfections Legionella was not recovered in both hot water plants. After the disinfection with chlorine dioxide (from June 2016 to May 2018), a statistically significant increase of iron, zinc and THM concentrations was detected in building A ( $\mathrm{p}=0.012 ; \mathrm{p}=0.004 ; \mathrm{p}=0.008)$. Both disinfectants appear effective against Legionella spp. growth in water network, but anolyte ensures a lower disinfection by-products release.
\end{abstract}




\section{Keywords}

Legionella, Anolyte, Chlorine Dioxide, Hot Water Disinfection

\section{Introduction}

Legionella spp. is a waterborne pathogen frequently associated with nosocomial infections, particularly among immunosuppressed, transplanted patients and people undergoing aggressive chemotherapy [1]. Over the last years in Europe, some of the outbreaks of Legionnaires' disease reported by the European surveillance scheme have been linked to hospitals and healthcare facilities having a hot water system colonized by Legionella spp. [2]. Moreover, international and Italian guidelines for Legionnaires' disease prevention [3] [4] suggest that ancient water networks of healthcare facilities provide optimal conditions for Legionella colonization into corroded pipelines and dead leg branches.

Hot water network treatments may be applied with different compounds such as chlorine dioxide [5], sodium hypochlorite [6], monochloramine [7] [8] and hydrogen peroxide [9] ensuring a continuous disinfection procedure. All these treatments are useful to control Legionella spp. counts, but some disinfectants may get worse the chemical water quality after the pipelines corrosion [10]. In fact, worldwide studies reported that high concentrations of toxic disinfection by-products (DBPs) in drinking water favor the probability to be taken up through inhalation, ingestion and dermal absorption, increasing the potential health risks of exposure for the users [11] [12]. For this reason, a planned choice of appropriate pipelines materials and chemical disinfection methods must be done for each healthcare water network [13].

Water disinfection may be achieved by new strategies, such as the electrochemically activated solution generators, which produce two solutions during electrochemically activation of dilute salt solutions: an oxidant solution capable of penetrating biofilm termed anolyte and a catholyte with detergent properties.

In detail, the dilute saline solution is activated by passing through a cylindrical electrolytic cell in which the anodic and cathodic chambers are separated by a permeable membrane. Two separate streams of activated water are produced: anolyte (hypochlorous acid) with a pH range of $2-6$ and an oxidation-reduction potential of $+400 \mathrm{mV}$ to $+1000 \mathrm{mV}$. It is an oxidizing compound having an antimicrobial effect. Catholyte (sodium hydroxide, $\mathrm{pH}$ of 12 and an oxidation-reduction potential of $-900 \mathrm{mV}$ ) has surfactant properties and is an antioxidant [14]. Several studies assert the efficacy of anolyte disinfection method in water [15], food [16] [17] and surface samples [18].

In Italian healthcare facilities, despite the increase of critical points linked to water disinfections, electrochemical methods are not frequently applied for hot water treatment. In fact, few published papers about water network disinfection have focused on the comparison between electrochemical and common chemical 
disinfection.

In this study, we report a plan for Legionnaires' disease prevention, which was scheduled to compare two different water disinfection strategies, applied in an Italian nursing home by using anolyte and chlorine dioxide, for continuous hot water disinfection. Considering the increase of Italian Legionnaires' disease cases linked to hospitals and healthcare facilities, this research may assess the choice of new strategies aimed to improve the chemical disinfection activity in hot water networks.

\section{Materials and Methods}

\subsection{Nursing Home Setting and Hot Water Disinfections}

The healthcare setting is a nursing home of North-Western Tuscany (Italy), organized in two identical buildings (A and B) active since 1975. For both buildings, the architectural structure is a monoblock with a central plate on 3 levels, with 13 rooms and 39 beds. Nursing home hosts non-self-sufficient elderly patients with cognitive and behavioral disorders and chronic degenerative diseases, such as Parkinson-Alzheimer's diseases, cardiovascular diseases, diabetes, etc.

In June 2016, within the Water Safety Plan (WSP) implementation program, the hot water system disinfection, and a systematic monitoring program with samplings at the final points of use, began.

Following the WSP introduction, the municipal drinking water was pre-filtered and softened before entering the two nursing home hot water distribution systems. Despite the old and galvanized steel-made pipelines, hot water networks were treated with in continuous chlorination.

Following a shock chlorination ( $50 \mathrm{mg} / \mathrm{L}$ sodium hypochlorite; $1 \mathrm{~h}$ ), a continuous disinfection with chlorine dioxide was applied in building $\mathrm{A}$, while anolyte compound was introduced in building $B$.

\subsection{Microbiological Hot Water Samplings and Legionella Spp. Research}

Before and after the WSP introduction, each building's hot water distribution system was sampled at the recirculation point (R) and at the boiler (B) of the central heating system and at two points of use located at the first and second floors (P1; P2) for Legionella detection, as suggested by Italian Legionnaires' guidelines [3]. Microbiological hot water samplings were performed on a monthly basis. From January 2017 samplings were done on a quarterly basis.

Legionella research and physical-chemical parameters assessment (total chlorine concentration, $\mathrm{pH}$ and water temperature) were recorded during the sampling activity.

Chlorine concentration was determined by the colorimetric Visocolor $\mathrm{HE}^{\circledR}$ test (Macherey-Nagel, Germany).

The isolation of Legionella spp. in hot water samples was performed as suggested by the international standards procedure ISO11731 [19]. Briefly, one liter 
of water was filtrated through a $0.2 \mu \mathrm{m}$ diameter membrane (Millipore, Billerica, $\mathrm{MA})$. The membrane was then immersed in $10 \mathrm{ml}$ of the same water and sonicated for 5 minutes, allowing the detachment of cells. The suspension was thermal-inactivated at $50^{\circ} \mathrm{C}$ for 30 minutes. Afterwards $0.1 \mathrm{ml}$ of the suspension was plated on Legionella BMPA selective medium (Oxoid Ltd, Basingstoke, Hampshire, UK) and the plates were incubated at $37^{\circ} \mathrm{C}$ for $7-10$ days within jars with a modified atmosphere $\left(2.5 \% \mathrm{CO}_{2}\right)$. Finally, almost $10 \%$ of the Legionella colonies grown on the medium were subjected to species and serogroup identification analysis using a multi-purpose latex agglutination test (Legionella Latex Test, Oxoid Ltd, Basingstoke, Hampshire, UK) and the Legionella pneumophila group sera set (Biogenetics, Italy).

\subsection{Chemical Hot Water Samplings and Analysis}

From June 2016, samplings for chemical analysis were performed at the point of aqueduct water entrance (Aq) and at the same sampling points chosen for microbiological tests. Chemical analyses were performed in June and December 2016; January, May, September 2017; January, May 2018. Chemical parameters such as iron $(\mathrm{Fe})$ ions, manganese $(\mathrm{Mn})$ ions, zinc $(\mathrm{Zn})$ ions and trihalomethanes compounds (THM) were researched as established by Council Directive 98/83/EC [20].

Metal ions were determined by ICP-MS (Inductively Coupled Plasma-Mass Spectrometry) according to EPA 6020B with an analytical error $<10 \%$ [21]. Samples for the determination of the solutes were filtered at $0.45 \mu \mathrm{m}$.

THM compounds were analyzed by GC-MS (Gas Chromatography-Mass Spectrometry) equipped with Purge \& Trap device following EPA 5030C and the EPA 8260D [22] [23]. The detection limits were $0.1 \mu \mathrm{g} / \mathrm{L}$ for tetra-chloro-ethylene and tri-chloro-ethylene and $0.01 \mu \mathrm{g} / \mathrm{L}$ for chloroform, bromoform, dichloro-bromo-methane, chloro-bromo-methane and 1,2 dichloro-ethane. The analytical error was $<10 \%$.

\subsection{Statistical Analysis}

The Kolmogorov-Smirnov test was performed to verify the normality of distributions. For each building, Kruskall-Wallis and Dunn tests were used to compare the chemical parameters concentrations detected during the continuous disinfection with chlorine dioxide and anolyte. Power tests were performed to estimate the sample sizes. The 1-beta values of the significant variables were $>0.8$, proving that the sample sizes were acceptable. A SPSS Version 17.0.1 (IBM Corp., Armonk, NY, USA) was used for the statistical analysis.

\section{Results}

\subsection{Legionella Spp. Results}

Before WSP implementation, between April 2016 and May 2016, high Legionella pneumophila sg1 concentrations were detected in all the tested water points of 
use. As shown in Figure 1, Legionella concentrations observed in hot water samples ranged from $1 \times 10^{4}$ to $3.5 \times 10^{4} \mathrm{CFU} / \mathrm{L}$, with a mean value of $2.4 \times 10^{4}$ $\pm 7.1 \times 10^{3} \mathrm{CFU} / \mathrm{L}$. Moreover, low temperature values were detected in all sampling points (mean value of $38.8^{\circ} \mathrm{C} \pm 4.2^{\circ} \mathrm{C}$ ).

Considering the absence of hot water disinfection, this data highlight a significant Legionella spp. colonization of both nursing home buildings water distribution systems.

After WSP plan introduction and the application of the two continuous disinfection methods, from June 2016 to June 2018 Legionella spp. was not recovered in both hot water networks.

\subsection{Physical and Chemical Results}

A good chemical quality was observed in all the hot water samples and all the values were within the limits recommended by Council Directive 98/83/EC (98/83/EC).

Table 1 shows iron, manganese, zinc ions and THM compounds detected on the point of aqueduct entrance (Aq) in the period between June 2016 and May 2018.

Iron ions values ranged from 22.8 to $28.4 \mu \mathrm{g} / \mathrm{L}$ (mean $24.9 \pm 1.9 \mu \mathrm{g} / \mathrm{L}$ ) (Council Directive 98/83/EC law limit $=200 \mu \mathrm{g} / \mathrm{L}$ ).

Zinc ions values ranged from 31 to $39 \mu \mathrm{g} / \mathrm{L}$ (mean $36.2 \pm 3 \mu \mathrm{g} / \mathrm{L}$ ) (Council Directive 98/83/EC law limit not provided).

Manganese ions values ranged from 1.3 to $1.5 \mu \mathrm{g} / \mathrm{L}$ (mean $1.4 \pm 0.08 \mu \mathrm{g} / \mathrm{L}$ ) (Council Directive 98/83/EC law limit $=50 \mu \mathrm{g} / \mathrm{L}$ ).

THM values ranged from 1.1 to $1.4 \mu \mathrm{g} / \mathrm{L}$ (mean $1.3 \pm 0.1 \mu \mathrm{g} / \mathrm{L})($ Council Directive 98/83/EC law limit $=30 \mu \mathrm{g} / \mathrm{L}$ ).

Table 2 shows physical-chemical results detected from the hot water network

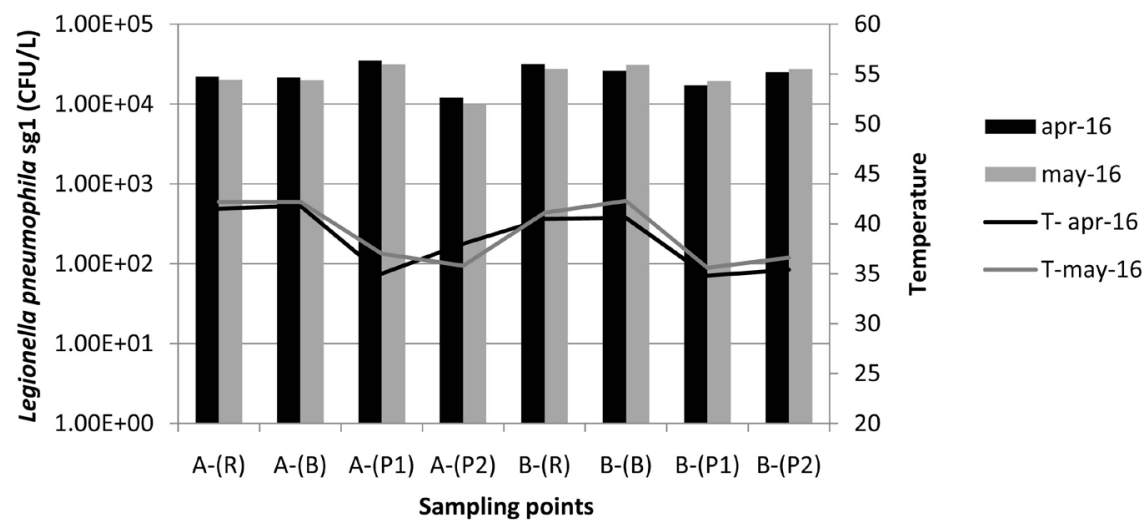

Figure 1. Legionella pneumophila sg1 counts and temperature values detected in all sampling points of building $A$ and $B$ before the application in hot water disinfections (April and May 2016). A-(R) = Building A-Recirculation; A-(B) = Building A-Boiler; A- $(\mathrm{P} 1)=$ Building A-Point of use 1; A-(P2) = Building A-Point of use 2; B-(R) = Building B-Recirculation; $\mathrm{B}-(\mathrm{B})=$ Building $\mathrm{B}-$ Boiler; $\mathrm{B}-(\mathrm{P} 1)=$ Building $\mathrm{B}-$ Point of use $1 ; \mathrm{B}-(\mathrm{P} 2)=$ Building B-Point of use 2. 
Table 1. Results of chemical analysis (iron ions, zinc ions, manganese ions, trihalomethanes compounds) performed on the point of aqueduct entrance in the period between June 2016 and May 2018.

\begin{tabular}{ccccc}
\hline \multicolumn{5}{c}{ POINT OF AQUEDUCT ENTRANCE $(\mathrm{Aq})$} \\
\hline MONTHS & IRON IONS $(\mu \mathrm{g} / \mathrm{L})$ & ZINC IONS $(\mu \mathrm{g} / \mathrm{L})$ & MANGANESE IONS $(\mu \mathrm{g} / \mathrm{L})$ & THMs $(\mu \mathrm{g} / \mathrm{L})$ \\
\hline June 2016 & 25.4 & 38.5 & 1.5 & 1.1 \\
December 2016 & 28.4 & 32.2 & 1.5 & 1.3 \\
January 2017 & 22.8 & 35.9 & 1.4 & 1.4 \\
May 2017 & 23.8 & 32 & 1.4 & 1.4 \\
September 2017 & 25.7 & 39 & 1.4 & 1.3 \\
January 2018 & 23.3 & 37.2 & 1.3 & 1.4 \\
May 2018 & 25 & 38.3 & 1.5 & 1.3 \\
\hline
\end{tabular}

Table 2. Mean values of total chlorine, temperature, $\mathrm{pH}$, iron ions, zinc ions, manganese ions, and trihalomethanes compounds detected from April 2016 to May 2018 in the hot water systems treated with chlorine dioxide (building A). (NP = Not Performed).

\begin{tabular}{|c|c|c|c|c|c|c|c|}
\hline \multicolumn{8}{|c|}{ Building A-(Chlorine Dioxide) } \\
\hline Months & $\begin{array}{c}\text { Total chlorine } \\
(\text { mean } \pm \text { SD mg/l) }\end{array}$ & $\begin{array}{c}\text { Temperature } \\
\left(\text { mean } \pm \mathrm{SD}^{\circ} \mathrm{C}\right)\end{array}$ & $\begin{array}{c}\text { Mean } \\
\mathrm{pH} \pm \mathrm{SD}\end{array}$ & $\begin{array}{c}\text { Iron Ions } \\
\text { (Mean } \pm S D \\
\mu G / L)\end{array}$ & $\begin{array}{c}\text { Zinc Ions } \\
\text { (Mean } \pm \text { SD } \\
\mu \mathrm{G} / \mathrm{L})\end{array}$ & $\begin{array}{c}\text { Manganese Ions } \\
(\text { Mean } \pm \text { SD } \\
\mu \mathrm{G} / \mathrm{L})\end{array}$ & $\begin{array}{c}\text { THMs } \\
(\text { Mean } \pm S D \\
\mu \mathrm{G} / \mathrm{L})\end{array}$ \\
\hline April 2016 & 0 & $41.5 \pm 2.1$ & $6.5 \pm 0.01$ & NP & NP & NP & NP \\
\hline May 2016 & 0 & $41.5 \pm 2$ & $6.5 \pm 0.01$ & NP & NP & NP & NP \\
\hline June 2016 & $0.3 \pm 0.04$ & $50.6 \pm 1.9$ & $6.5 \pm 0.01$ & $8.9 \pm 4.9$ & $54.7 \pm 10.3$ & $1.5 \pm 0.3$ & $2.1 \pm 0.2$ \\
\hline July 2016 & $0.26 \pm 0.05$ & $49.9 \pm 2.3$ & $7 \pm 0.03$ & NP & NP & NP & NP \\
\hline August 2016 & $0.34 \pm 0.11$ & $50.6 \pm 2.4$ & $6.5 \pm 0.02$ & NP & NP & NP & NP \\
\hline September 2016 & $0.37 \pm 0.10$ & $50.7 \pm 2$ & $6.5 \pm 0.02$ & NP & NP & NP & NP \\
\hline October 2016 & $0.42 \pm 0.08$ & $50.6 \pm 2,3$ & $6.5 \pm 0.02$ & NP & NP & NP & NP \\
\hline November 2016 & $0.30 \pm 0.06$ & $43.8 \pm 3,1$ & $6.4 \pm 0.03$ & NP & NP & NP & NP \\
\hline December 2016 & $0.32 \pm 0.05$ & $48.8 \pm 4,7$ & $6.7 \pm 0.04$ & $22.2 \pm 5.2$ & $86.2 \pm 9.5$ & $1.5 \pm 0.4$ & $9.7 \pm 2$ \\
\hline January 2017 & $0.31 \pm 0.06$ & $50.1 \pm 3.5$ & $6.7 \pm 0.02$ & $22.8 \pm 7.4$ & $85.7 \pm 9.3$ & $1.7 \pm 0.3$ & $13.2 \pm 3.4$ \\
\hline May 2017 & $0.36 \pm 0.09$ & $50.9 \pm .2 .9$ & $6.8 \pm 0.03$ & $22.9 \pm 7.5$ & $88.6 \pm 9.8$ & $1.9 \pm 0.5$ & $13.8 \pm 5.1$ \\
\hline September 2017 & $0.41 \pm 0.06$ & $52.4 \pm 3.2$ & $6.5 \pm 0.01$ & $22.4 \pm 8.8$ & $86.1 \pm 9.2$ & $1.7 \pm 0.5$ & $13.8 \pm 5$ \\
\hline January 2018 & $0.38 \pm 0.08$ & $53 \pm 3.2$ & $6.5 \pm 0.03$ & $23.4 \pm 8.3$ & $86.1 \pm 9.2$ & $1.7 \pm 0.5$ & $14.8 \pm 5.2$ \\
\hline May 2018 & $0.39 \pm 0.05$ & $52.2 \pm 2.8$ & $6.4 \pm 0.01$ & $24.7 \pm 8.5$ & $93 \pm 11.8$ & $1.7 \pm 0.1$ & $14.8 \pm 4.7$ \\
\hline
\end{tabular}

treated with chlorine dioxide (building A) in the period between June 2016 and May 2018.

Mean temperature and values were between $43.8^{\circ} \mathrm{C} \pm 3.1^{\circ} \mathrm{C}$ (November 2016) and $53^{\circ} \mathrm{C} \pm 3.2^{\circ} \mathrm{C}$ (January 2018) while mean $\mathrm{pH}$ values were between $6.5 \pm 0.01$ to $7 \pm 0.03$.

From June 2016 mean total chlorine concentration were between $0.26 \pm 0.05$ $\mathrm{mg} / \mathrm{L}$ (July 2016) to $0.42 \pm 0.08 \mathrm{mg} / \mathrm{L}$ (October 2016). 
Mean iron ions values ranged from $8.9 \pm 4.9 \mu \mathrm{g} / \mathrm{L}$ (June 2016) to $24.7 \pm 8.5$ $\mu \mathrm{g} / \mathrm{L}$ (May 2018) (Council Directive 98/83/EC law limit $=200 \mu \mathrm{g} / \mathrm{L}$ ).

Mean zinc ions values ranged from $54.7 \pm 10.3 \mu \mathrm{g} / \mathrm{L}$ (June 2016) to $93 \pm 11.8$ $\mu \mathrm{g} / \mathrm{L}$ (May 2018) (Council Directive 98/83/EC law limit not provided).

Mean manganese ions values ranged from $1.5 \pm 0.3 \mu \mathrm{g} / \mathrm{L}$ (June 2016) to $1.9 \pm$ $0.5 \mu \mathrm{g} / \mathrm{L}$ (May 2017) (Council Directive 98/83/EC law limit $=50 \mu \mathrm{g} / \mathrm{L}$ ).

Mean THM values ranged from $2.1 \pm 0.2 \mu \mathrm{g} / \mathrm{L}$ (June 2016) to $14.8 \pm 5.2 \mu \mathrm{g} / \mathrm{L}$ (January 2018) (Council Directive 98/83/EC law limit $=30 \mu \mathrm{g} / \mathrm{L}$ ).

Statistically significant increases of iron, zinc and THM concentrations were detected after the disinfection with chlorine dioxide (from June 2016 to May 2018) ( $\mathrm{p}=0.012 ; \mathrm{p}=0.004 ; \mathrm{p}=0.008)$.

Table 3 shows physical-chemical results detected from the hot water network treated with anolyte (building B) in the period between June 2016 and May 2018.

Mean temperature and values were between $39.8^{\circ} \mathrm{C} \pm 3.3^{\circ} \mathrm{C}$ (April 2016) and $43.1^{\circ} \mathrm{C} \pm 2.9^{\circ} \mathrm{C}$ (October 2016) while mean $\mathrm{pH}$ values were between $6.4 \pm 0.02$ to $6.7 \pm 0.03$.

From June 2016 mean total chorine concentration were between $0.2 \pm 1.4$ $\mathrm{mg} / \mathrm{L}$ (September 2016) to $0.35 \pm 0.2 \mathrm{mg} / \mathrm{L}$ (September 2017).

Mean iron ions values ranged from $32.2 \pm 8.6 \mu \mathrm{g} / \mathrm{L}$ (June 2016) to $36.4 \pm 9$ $\mu \mathrm{g} / \mathrm{L}$ (September 2017) (Council Directive 98/83/EC law limit = $200 \mu \mathrm{g} / \mathrm{L}$ ).

Table 3. Mean values of total chlorine, temperature, $\mathrm{pH}$, iron ions, zinc ions, manganese ions, and trihalomethanes compounds detected from April 2016 to May 2018 in the hot water systems treated with anolyte (building B). (NP = Not Performed).

\begin{tabular}{|c|c|c|c|c|c|c|c|}
\hline \multicolumn{8}{|c|}{ Building B-(Anolyte) } \\
\hline Months & $\begin{array}{c}\text { Total Chlorine } \\
(\text { mean } \pm \text { SD mg/L) }\end{array}$ & $\begin{array}{c}\text { Temperature } \\
\left(\text { mean } \pm \mathrm{SD}^{\circ} \mathrm{C}\right)\end{array}$ & $\begin{array}{c}\text { Mean } \\
\mathrm{pH} \pm \mathrm{SD}\end{array}$ & $\begin{array}{c}\text { Iron Ions } \\
\text { (mean } \pm S D \\
\mu g / L)\end{array}$ & $\begin{array}{c}\text { Zinc Ions } \\
\text { (mean } \pm \text { SD } \\
\mu \mathrm{g} / \mathrm{L})\end{array}$ & $\begin{array}{l}\text { Manganese Ions } \\
(\text { mean } \pm S D \mu g / L)\end{array}$ & $\begin{array}{c}\text { THMs } \\
\text { (mean } \pm \text { SD } \\
\mu \mathrm{g} / \mathrm{L})\end{array}$ \\
\hline April 2016 & 0 & $39.8 \pm 3.3$ & $6.5 \pm 0.01$ & NP & NP & NP & NP \\
\hline May 2016 & 0 & $42.1 \pm 1.9$ & $6.5 \pm 0.02$ & NP & NP & NP & NP \\
\hline June 2016 & $0.27 \pm 0.7$ & $43 \pm 2$ & $6.5 \pm 0.01$ & $32.2 \pm 8.6$ & $41.8 \pm 7.3$ & $1.4 \pm 0.2$ & $1.2 \pm 0.2$ \\
\hline July 2016 & $0.22 \pm 0.8$ & $43 \pm 2.2$ & $6.5 \pm 0.02$ & NP & NP & NP & NP \\
\hline August 2016 & $0.21 \pm 1.1$ & $42.8 \pm 2.7$ & $6.6 \pm 0.03$ & NP & NP & NP & NP \\
\hline September 2016 & $0.2 \pm 1.4$ & $42.6 \pm 2.5$ & $6.4 \pm 0.02$ & NP & NP & NP & NP \\
\hline October 2016 & $0.23 \pm 1.7$ & $43.1 \pm 2.9$ & $6.5 \pm 0.01$ & NP & NP & NP & NP \\
\hline November 2016 & $0.22 \pm 1.5$ & $39.2 \pm 3$ & $6.5 \pm 0.01$ & NP & NP & NP & NP \\
\hline December 2016 & $0.25 \pm 1$ & $40.5 \pm 2.8$ & $6.5 \pm 0.01$ & $33.2 \pm 6.4$ & $44.4 \pm 8.2$ & $1.5 \pm 0.5$ & $1.9 \pm 0.9$ \\
\hline January 2017 & $0.29 \pm 1.2$ & $42 \pm 3.1$ & $6.5 \pm 0.02$ & $34 \pm 9.9$ & $45.5 \pm 10.6$ & $1.6 \pm 0.5$ & $2.2 \pm 0.3$ \\
\hline May 2017 & $0.3 \pm 0.9$ & $41.1 \pm 1.7$ & $6.4 \pm 0.02$ & $36.1 \pm 8.8$ & $42.5 \pm 6.5$ & $1.4 \pm 0.3$ & $2 \pm 0.4$ \\
\hline September 2017 & $0.35 \pm 0.2$ & $40.9 \pm 1.4$ & $6.6 \pm 0.02$ & $36.4 \pm 9$ & $43.1 \pm 8.4$ & $1.4 \pm 0.4$ & $1.8 \pm 0.8$ \\
\hline January 2018 & $0.3 \pm 0.4$ & $41.2 \pm 2.4$ & $6.7 \pm 0.03$ & $35.5 \pm 5.8$ & $42.5 \pm 5.3$ & $1.6 \pm 0.5$ & $2 \pm 0.6$ \\
\hline May 2018 & $0.32 \pm 0.4$ & $41.6 \pm 2.5$ & $6.5 \pm 0.03$ & $34.3 \pm 10.8$ & $42.2 \pm 6.7$ & $1.6 \pm 0.5$ & $2.2 \pm 0.6$ \\
\hline
\end{tabular}


Mean zinc ions values ranged from $41.8 \pm 7.3 \mu \mathrm{g} / \mathrm{L}$ (June 2016) to $45.5 \pm 10.6$ $\mu \mathrm{g} / \mathrm{L}$ (January 2017) (Council Directive 98/83/EC law limit not provided).

Mean manganese ions values ranged from $1.4 \pm 0.2 \mu \mathrm{g} / \mathrm{L}$ (June 2016) to $1.6 \pm$ $0.5 \mu \mathrm{g} / \mathrm{L}$ (May 2018) (Council Directive 98/83/EC law limit $=50 \mu \mathrm{g} / \mathrm{L}$ ).

Mean THM values ranged from $1.2 \pm 0.2 \mu \mathrm{g} / \mathrm{L}$ (June 2016) to $2.2 \pm 0.6 \mu \mathrm{g} / \mathrm{L}$ (May 2018) (Council Directive 98/83/EC law limit $=30 \mu \mathrm{g} / \mathrm{L}$ ).

No Statistically significant increases of ions and THM concentrations were detected after the disinfection with chlorine dioxide (from June 2016 to May 2018) $(\mathrm{p}>0.05)$.

\section{Discussion}

According to literature, the application of a plan for Legionella prevention and control is needed in healthcare facilities, mostly in hospitals hosting immunosuppressed patients [24]. Considering some occurrences of Legionnaires' disease outbreaks in nursing homes [25] [26] [27], the implementation of the Water Safety Plan may also be extended to these kinds of healthcare settings.

For this reason, Italian guidelines for Legionnaires' disease prevention and control [3] recommend the application of control measures ensuring a good microbiological quality in water networks. In fact, the choice of an adequate and continuous chemical disinfection system may prevent the occurrence of waterborne pathogens colonization in water pipelines, mostly in high and ancient buildings with large and complex water network having critical points [28] [29].

Despite literature data assert that chlorine dioxide enhances the corrosion process of metal ions, which may be released in drinking water, this is the most common chemical compound disinfectant used for hot water disinfection. In fact, treatment with chlorine dioxide is effective against bacteria, virus and protozoa. If not controlled carefully, chlorine dioxide can corrode pipelines releasing metal ions and disinfection by-products in drinking water, getting worse the organoleptic properties of water [30].

Moreover, alternative techniques using electrochemically-activated solutions are less used, and only few studies support this method for the prevention of microbiological water risk.

Anolyte, applied for drinking water disinfection, can act directly on the biofilm inside the plumbing, eliminating it in few days. It is highly effective in disinfection processes against bacteria (including spores), virus and protozoa. Treatment has low operating costs and the neutral $\mathrm{pH}$ is fully compatible with the materials of water networks. Moreover, anolyte does not cause excessive corrosion of pipework [31].

Our comparative study shows how chlorine dioxide and anolyte are able to avoid Legionella spp. growth in both water networks in a long-term period. Although in two years study we always observed a good chemical quality of drinking waters, some statistically significant differences were detected between building A and B. In details, from hot water network treated with chlorine dioxide we observed an increase of metal ions (iron and zinc) and THM concentra- 
tions in the period between June 2016 and May 2018. This trend was not detected in hot water samplings collected from building B and disinfected with anolyte. However, during the whole period of study chemical results of water sampling collected from the point of aqueduct entrance remained unchanged. Despite this comparison may confirm the advantage and disadvantage declared in literature, the choice of an appropriate disinfection method for hot drinking water may be continuously controlled as described by the Water Safety Plan [28] [30] [31].

\section{Conclusion}

In conclusion, our study is one of the few assessing a technical comparison of two different incontinuous disinfections, which were applied in two separate, similar and pre-contaminated hot water networks. After two years, it is possible to assert that both disinfectants appear effective against Legionella pneumophila sg1 growth in water pipelines, but anolyte ensures a lower metal ions and disinfection by-products (THM) release.

\section{Acknowledgements}

The technical support of the University of Pisa PRA-2017-18 project entitled "Strategies of diagnosis, prevention, and treatment of medical device-associated infections" is gratefully acknowledged.

\section{Conflicts of Interest}

All authors have no conflict of interest to declare.

\section{References}

[1] Muldrow, L.L., Tyndall, R.L. and Fliermans, C.B. (1982) Application of Flow Cytometry to Studies of Pathogenic Free-Living Amoebae. Applied and Environmental Microbiology, 44, 1258-1269.

[2] European Centre for Disease Prevention and Control (2017) Legionnaires' Disease-Annual Epidemiological Report 2017 [2015 data], Stockholm.

[3] Superior Institute of Health (2015) Linee Guida per la Prevenzione ed il Controllo Della Legionellosi. Rome.

[4] World Health Organization (2007) Legionella and the Prevention of Legionellosis, Geneva.

[5] Borella, P., Bargellini, A., Marchegiano, P., Vecchi, E. and Marchesi, I. (2016) Hospital-Acquired Legionella Infections: An Update on the Procedures for Controlling Environmental Contamination. Annali di Igiene, 28, 98-108.

[6] Orsi, G.B., Vitali, M., Marinelli, L., Ciorba, V., Tufi, D., Del Cimmuto, A., Ursillo, P., Fabiani, M., De Santis, S., Protano, C., Marzuillo, C. and De Giusti, M. (2014) Legionella Control in the Water System of Antiquated Hospital Buildings by Shock and Continuous Hyperchlorination: 5 Years Experience. BMC Infectious Diseases, 14, 394. https://doi.org/10.1186/1471-2334-14-394

[7] Casini, B., Baggiani, A., Totaro, M., Mansi, A., Costa, A.L., Aquino, F., Miccoli, M., Valentini, P., Bruschi, F., Lopalco, P.L. and Privitera, G. (2018) Detection of Viable 
but Non-Culturable Legionella in Hospital Water Network Following Monochloramine Disinfection. Journal of Hospital Infection, 98, 46-52. https://doi.org/10.1016/j.jhin.2017.09.006

[8] Casini, B., Buzzigoli, A., Cristina, M.L., Spagnolo, A.M., Del Giudice, P., Brusaferro, S., Poscia, A., Moscato, U., Valentini, P., Baggiani, A. and Privitera, G. (2014) Long-Term Effects of Hospital Water Network Disinfection on Legionella and Other Waterborne Bacteria in an Italian University Hospital. Infection Control \& Hospital Epidemiology, 35, 293-299. https://doi.org/10.1086/675280

[9] Casini, B., Aquino, F., Totaro, M., Miccoli, M., Galli, I., Manfredini, L., Giustarini, C., Costa, A.L., Tuvo, B., Valentini, P., Privitera, G. And Baggiani, A. (2017) Application of Hydrogen Peroxide as an Innovative Method of Treatment for Legionella Control in a Hospital Water Network. Pathogens, 6, 15. https://doi.org/10.3390/pathogens6020015

[10] Marchesi, I., Ferranti, G., Mansi, A., Marcelloni, A.M., Proietto, A.R., Saini, N., Borella, P. and Bargellini, A. (2016) Control of Legionella Contamination and Risk of Corrosion in Hospital Water Networks Following Various Disinfection Procedures. Applied and Environmental Microbiology, 82, 2959-2965.

https://doi.org/10.1128/AEM.03873-15

[11] Zhai, H., Zhang, X., Zhu, X., Liu, J. and Ji, M. (2014) Formation of Brominated Disinfection Byproducts during Chloramination of Drinking Water: New Polar Species and Overall Kinetics. Environmental Science \& Technology, 48, 2579-2588. https://doi.org/10.1021/es4034765

[12] Richardson, S.D., Plewa, M.J., Wagner, E.D., Schoeny, R. and Demarini, D.M. (2007) Occurrence, Genotoxicity, and Carcinogenicity of Regulated and Emerging Disinfection By-Products in Drinking Water: A Review and Roadmap for Research. Mutation Research/Reviews in Mutation Research, 636, 178-242. https://doi.org/10.1016/j.mrrev.2007.09.001

[13] Totaro, M., Valentini, P., Costa, A.L., Giorgi, S., Casini, B. and Baggiani, A. (2018) Rate of Legionella pneumophila Colonization in Hospital Hot Water Network after Time Flow Taps Installation. Journal of Hospital Infection, 98, 60-63.

https://doi.org/10.1016/j.jhin.2017.08.021

[14] O’Donnell, M.J., Boyle, M., Swan, J., Russell, R.J. and Coleman, D.C. (2009) A Centralised, Automated Dental Hospital Water Quality and Biofilm Management System Using Neutral Ecasol Maintains Dental Unit Waterline Output at Better than Potable Quality: A 2-Year Longitudinal Study. Journal of Dentistry, 37, 748-762. https://doi.org/10.1016/j.jdent.2009.06.001

[15] Li, Y., Li, Y., Liu, Z., Wu, T. and Tian, Y. (2011) A Novel Electrochemical Ion Exchange System and Its Application in Water Treatment. Journal of Environmental Sciences (China), 23, S14-S17. https://doi.org/10.1016/S1001-0742(11)61069-3

[16] Ayebah, B., Hung, Y.C., Kim, C. and Frank, J.F. (2006) Efficacy of Electrolyzed Water in the Inactivation of Planktonic and Biofilm Listeria monocytogenes in the Presence of Organic Matter. Journal of Food Protection, 69, 2143-2150. https://doi.org/10.4315/0362-028X-69.9.2143

[17] Ayebah, B., Hung, Y.C. and Frank, J.F. (2005) Enhancing the Bactericidal Effect of Electrolyzed Water on Listeria monocytogenes Biofilms Formed on Stainless Steel. Journal of Food Protection, 68, 1375-1380. https://doi.org/10.4315/0362-028X-68.7.1375

[18] Swan, J.S., Deasy, E.C., Boyle, M.A., Russell, R.J., O’Donnell, M.J. and Coleman, D.C. (2016) Elimination of Biofilm and Microbial Contamination Reservoirs in 
Hospital Washbasin U-Bends by Automated Cleaning and Disinfection with Electrochemically Activated Solutions. Journal of Hospital Infection, 94, 169-174. https://doi.org/10.1016/j.jhin.2016.07.007

[19] International Organization for Standardization ISO 11731 Water Quality Enumeration of Legionella, Geneva 2017.

[20] Council Directive 98/83/EC of 3 November 1998 on the Quality of Water Intended for Human Consumption, Bruxelles.

[21] United States Environmental Protection Agency (2014) EPA Method 6020B (SW-846): Inductively Coupled Plasma. Mass Spectrometry. Washington DC.

[22] United States Environmental Protection Agency (2014) EPA Method 8260D: Volatile Organic Compounds by Gas Chromatography/Mass Spectrometry (GC/MS). Washington DC.

[23] United States Environmental Protection Agency (2003) 5030C (SW-846): Purge-and-Trap for Aqueous Samples. Washington DC.

[24] Kanamori, H., Weber, D.J. and Rutala, W.A. (2016) Healthcare Outbreaks Associated with a Water Reservoir and Infection Prevention Strategies. Clinical Infectious Diseases, 62, 1423-1435. https://doi.org/10.1093/cid/ciw122

[25] Trop Skaza, A., Beskovnik, L., Storman, A., Ursic, S., Groboljsek, B. and Kese, D. (2010) Outbreak of Legionnaires' Disease in a Nursing Home, Slovenia, August 2010: Preliminary Report. Eurosurveillance, 15, 19672.

[26] Carratalà, J. and Garcia-Vidal, C. (2010) An Update on Legionella. Current Opinion in Infectious Diseases, 23, 152-157. https://doi.org/10.1097/QCO.0b013e328336835b

[27] Seenivasan, M.H., Yu, V.L. and Muder, R.R. (2005) Legionnaires' Disease in Long-Term Care Facilities: Overview and Proposed Solutions. Journal of the American Geriatrics Society, 53, 875-880. https://doi.org/10.1111/j.1532-5415.2005.53270.x

[28] Totaro, M., Valentini, P., Costa, A.L., Frendo, L., Cappello, A., Casini, B., Miccoli, M., Privitera, G. and Baggiani, A. (2017) Presence of Legionella spp. in Hot Water Networks of Different Italian Residential Buildings: A Three-Year Survey. International Journal of Environmental Research and Public Health, 14, pii: E1296. https://doi.org/10.3390/ijerph14111296

[29] Baggiani, A., Casini, B., Totaro, M., Aquino, F., Valentini, P., Bruni, B., Porretta, A., Casalini, F., Miccoli, M. and Privitera, G. (2015) Colonization by Legionella spp. of Water Networks in Residential Buildings of the Province of Pisa, Italy. Annali di igiene, 27, 718-25.

[30] Zhang, H., Tian, Y., Kang, M., Chen, C., Song, Y. and Li, H. (2019) Effects of Chlorination/Chlorine Dioxide Disinfection on Biofilm Bacterial Community and Corrosion Process in a Reclaimed Water Distribution System. Chemosphere, 215, 62-73. https://doi.org/10.1016/j.chemosphere.2018.09.181

[31] Deasy, E.C., Moloney, E.M., Boyle, M.A., Swan, J.S., Geoghegan, D.A., Brennan, G.I., Fleming, T.E., O’Donnell, M.J. and Coleman, D.C. (2018) Minimizing Microbial Contamination Risk Simultaneously from Multiple Hospital Washbasins by Automated Cleaning and Disinfection of U-Bends with Electrochemically Activated Solutions. Journal of Hospital Infection, 100, e98-e104.

https://doi.org/10.1016/j.jhin.2018.01.012 